\title{
Factors Affecting Employee Engagement: A Case of ABC Company, Indonesia
}

\section{Sylvia Angelina}

Faculty of Economics and Business, Universitas Pelita Harapan, Indonesia

Innocentius Bernarto* Faculty of Economics and Business, Universitas Pelita Harapan, Indonesia bernarto227@gmail.com

\section{Yohana, F. Cahya Palupi} Meilani

Faculty of Economics and Business, Universitas Pelita Harapan, Indonesia

${ }^{*}$ Corresponding author

\begin{abstract}
This study aims to examine factors affecting employee engagement at $A B C$ company. This study was done in a quantitative manner. There were five variables used, including goal setting, job autonomy, strategic attention, role benefit, and employee engagement. The data was collected by using a questionnaire distributed to all 100 employees at $\mathrm{ABC}$ company (census). The questionnaire also covered the respondents' profile including their gender, age, educational background, and length of work. The data was analyzed by using PLS-SEM in SmartPls program. The results conclude that goal setting, job autonomy, strategic attention, and role benefit were positively influenced employee engagement at $A B C$ company. The contribution of this study is to give input for managerial $A B C$ company and other oil companies in maintaining employee engagement.
\end{abstract}

Keywords: Goal Setting, Job Autonomy, Strategic Attention, Role Benefits, Employee Engagement

\section{INTRODUCTION}

In Human Resource Management perspective, the employee is the most critical resources that must be well managed to achieve the organization's higher performance. Because of that reason, the organization should manage the employee well by understanding employee engagement as one of the elements that must be maintained. As King (2010) stated that employee engagement is one of the important factor in business to survive, human resource (HR) manager must be able to determine the strategy that should be used to create employee engagement. Meanwhile, goal setting, job autonomy, strategic attention, and role benefit are also found to have a strong relationship with employee engagement. Employee engagement will affect quality service. By providing a better quality of service, the company will be able to minimize the turnover intention, thus resulting in higher employee engagement. A senior employee engagement enables the HR manager to establish a strong relationship with the company. 
HR management plays a vital role in identifying and understanding employee engagement. Understanding the employee's need helps HR influencing employee behavior to help the company to survive in the competition for the long term. Employee engagement is a primary thing that should be considered by the managerial level at any company. It is believed that employee engagement is a result of the globalization era and the HR, and top management of a company should be concerned about it to survive. It is defined as a level of commitment and employee involvement in achieving the organization's visions and missions. The engaged employees understand how the company's business; thus they will work together and strive for performance improvement and the company's excellence. It is considered as a positive behavior performed by the employees for the company. Engagement in the workplace was conceptualized by Kahn, (1990) as the utilization of internal stakeholders' roles. During their work, the employees work and express themselves physically, cognitively, and emotionally in their performance. The importance of employee engagement is that the employees will feel bounded and stay in the company, which simultaneously will have an impact on improving the employee performance and giving advantages to the company to succeed in the future. In big companies, employee engagement results in better performance. In contrast, a low employee engagement makes the employees feel not tied. Thus, they perform less optimally, and in the long term, the company will have less opportunity to succeed.

Kahn (1990) proposed three aspects of engagement, such as physical, cognitive, and emotional aspects. Job satisfaction belongs to the cognitive side. In an HR perspective, one of the main focuses in employee engagement has a lot to do with how employees feel about working experience and how they are treated in the organization. Emotions are involved and influence the success of an organization. In many cases, some employees are found to be difficult to give their best at work regardless of how hard the $\mathrm{HR}$ and managers try to involve them. On the other hand, most employees expect them to be committed to the company for financial purposes, be connected with the company, and in the long term, they want to contribute to significant progress.

Oil and gas companies are considered to have considerable potential to improve the economy of a country. They have an important and strategic role. In addition to the gas and oil being used in daily life, they are a source of energy for national economic activities. This sector contributes to foreign country exchange earnings, and in the early days, it has the largest portion of state revenues. The $A B C$ company is one of the companies working in this sector. Then, Radda et al. (2015) stated many research on employee engagement but less research on employee engagement in the oil companies. In the oil company, HR also struggling to seek a good way to retain employees, decrease turnover, and increase productivity. For an oil companies, the model of employee engagement attached with performance and intention to stay, which is there are affected by some aspects such as job satisfaction, job content, job flexibility.

Based on the interview and data from the HR manager in ABC Company, the expected, achieved target was $100 \%$, but only $65 \%$ of theemployee could meet the goal and work enthusiastically. This indicated a problem where the reality did not meet the expectancy 
and that employee engagement was not optimal. Interviews with several employees concluded that they did not work intensively, and felt exhausted although they considered their job meaningful. Therefore, there is such a need to research on the factors influencing employee engagement in $A B C$ Company.

The problem that faced by the $A B C$ Company is about the low employee engagement in this company and also this supported with an interview with some employees that stated they did not work intensively, they say their job is significant, but their job exhausts their energy. Therefore, it is interesting to do research related to the factor affecting employee engagement in $A B C$ Company. Because of the phenomena gap, so will be further elaborated in the research problem that is how to increase employee engagement in the company. Based on the background problem discussed above, these are the purpose of this study strives to examine: Goal setting in $A B C$ Company positively related to employee engagement; Job autonomy in $A B C$ Company positively related to employee engagement; Strategic attention in $A B C$ Company positively related to employee engagement; The role benefit in $A B C$ Company positively related to employee engagement.

\section{THEORETICAL REVIEW}

\section{Employee Engagement}

Employee engagement becomes the main focus of this research considering its importance for company performance. It includes an emotional commitment to where they work and the goals of a company. It explains that the employees put their concern on the progress of a company and the quality of the work they produce. This shows that they feel valued and belong to the company. Thus, they will establish a stronger relationship with the company. In the long term, this will bring several benefits such as encouraging engagement, morale, loyalty, and productivity to a higher place. According to Saks and Gruman (2011), the right incentive programs could improve team performance by up to $44 \%$, encourage employee engagement up to $27 \%$, and attract potential and qualified employees to join. When the employees are comfortable with their work and where they work, they will work harder to show their best performance and tend to be loyal in a long time to the company. They will also come to the office every day working happily, and putting more smiles on their faces, and vice versa where if they do not have a strong relationship with the company, they may tend to think of other things that have nothing to do with their work and start looking for other jobs.

Employee engagement is an equation where the management of a company requires a level of satisfaction and awareness before they build understanding and commitment from their employees (Chughtai \& Buckley, 2011). Employee dissatisfaction is the main obstacle in building employee engagement. Those who feel unhappy with the place where they work will have an impact on performance and productivity that tends to fall. In contrast, a company that has a pleasant working atmosphere for employees will finish their workloads and achieve a high target due to increasing the performance and 
productivity. The leader should identify the employee dissatisfaction to meet the goals set to determine strategic steps to increase the level of employee satisfaction.

When the employees believe that their leaders will improve their welfare, it is thought that the organization will move one step forward into the process of engagement. This condition is where a team makes an agreement to gain awareness in facing established business targets. To do this effectively, a group leader must create an internal condition that supports the achievement of daily work. With the increase of high awareness in the employees' perspective, the achievement of predetermined business targets can be achieved with a sense of togetherness, and each individual helps each other in completing the work. A leader must be able to establish a good communication between the employees so that any problems that arise from each job will be easily resolved.

A high level of awareness may help each employee to understand that the changes made by the company are not an option but an important thing that must be done together with a strong team. Therefore, each employee will contribute. Once the group leader is not focused on doing the work to bring the group to success, it will result in making the employees anxious in doing the work. The right direction from the leader helps the employees in achieving the targets, including the goals' direction and how to make them. Management requires an investment in potential time and money resources into proper forms of communication, which is an important information for all employees. Sharing a clear mission and a right mindset in carrying out good work is one way to bring all employees into the company's business with the same mindset and steps. Each employee must be given a clear direction and know-how to succeed with the company they work in. This pattern aims to increase a sense of ownership and to make each employee feels that they are an essential part of the company. A leadership role is needed in creating a mindset and perspective on the company. It makes the employees feel comfortable when the leadership they follow understands well about the direction of the company. As a result, a strong team will be formed to help companies achieve their business goals.

Sheemun et al. (2013) findings that goal setting, job autonomy, strategic attention, and role benefit will give impact to employee engagement. In a goal-setting approach, good employee performance in organizing public services is identified as its goal. While jobs providing flexible work schedules and autonomy procedures will make the employees to be more responsible for their work. People with a high level of work autonomy know that they are personally responsible for both success and failure of the job. But, Hackman and Oldham, (1976) mentioned this concept as the experience on how to be accountable. There is direct and transparent information on performance (feedback) which makes the employee knows how effective the business is. Feedback is very influential when it comes to the job itself. The combined dimensions affect the employee's psychological state. The higher the score on each characteristic, the higher the motivation, performance, and job satisfaction (Hackman \& Oldham, 1976). Then mental state refers to the experience of being meaningful, responsible, and knowledge of results. When this situation happens, someone tends to have positive feelings 
towards performance is considered excellent. This is in line with the definition of employee engagement, which also involves positive feelings or reactions to work, organizations, and the values of the organization itself. The employees who are engaged have the motivation, high job satisfaction, and low rates of absenteeism turnover (Elanain, 2009).

Dobre (2013) stated strategic attention refers to the willingness of an employee to make higher achievements for the company's purpose. In addition, it is the employee's effort to reach the company vision and mission. Therefore, the higher the strategic attention, the higher the employee engagement and Dobre (2013) still conclude that the higher role benefit, the better the employee engagement. Robbins (2003)stated that employee engagement is a positive attitude held by an employee on the organization and its values. When an employee is engaged, he/she will be aware of the business context and works with colleagues to improve their performance for the advantages of the organization. On contrary, Prabhakar (2011) argued that when employees are not engaged, they are unproductive and wasting time while working. The involved employee will show that they are aware of the organization's goal and maintain good teamwork. As a result, the organization will be benefited and obtain the expected engagement in a two-way relationship between the employer and employees.

Schaufeli and Bakker (2010) stated that employee engagement is a good perception related to work involving enthusiasm, dedication, and absorption. It is characterized by a high level of energy and right mentality when working, and a desire to have a harder and stronger business in facing difficulties. Dedication refers to one's involvement in work and work experience, enthusiasm, inspiration, pride, and challenges. Absorption is characterized by thoughts that are happy at work, so time passes quickly, and difficulties cannot prevent them from working.

Previous studies by Prabhakar (2011); Chughtai and Buckley (2011); Saks and Gruman, (2011) defined employee engagement concept as a measure of how employees get a positive feeling and motivated to make more positive impacts on work and relationship with co-workers. Although many studies agree to underline that it shapes the employees emotionally and attitude at work, some previous studies concluding it as an internal motivation or a desire to target the highest performance achievement. Anaza and Rutherford (2012) added the importance of supervisor support to maintain engagement as an intangible factor. Saks (2019) stated that engagement could bring Social Exchange Theory (SET) that explained different stages of engagement in different companies. Kahn (1990) clearly emphasized that working depended on the available facilities and resources provided by the organization. If the organization fails to provide good facilities and resources, the employees will simultaneously feel disengaged. Therefore, it is highly important to maintain the rewards system as a recognition to build employee engagement. Sheemun et al. (2013) conducted a research in Malaysia's private sector also found that job autonomy, goal setting, and role benefit could measure the employee engagement. Thus, organizations need to understand the factors affecting employee engagement. 


\section{Development of Hypothesis}

\section{Relationship between Goal Setting and Employee Engagement}

Several studies by Ashraf et al., (2012); Bezuijen et al., (2010); Medlin \& Green, (2009) finding that clear direction of a goal setting. Inline with Slåtten and Mehmetoglu (2011) that the better of goal-setting, the better employee engagement with the organization. Thus, goal setting affected positively for employee engagement. For this reason, the first hypothesis that can be proposed is as follows:

$\mathrm{H}_{1}$ : Goal setting positively influences employee engagement.

\section{Relationship between Job Autonomy and Employee Engagement}

Several studies agreed on the importance of giving some freedom to do job, independence, and also discretion for employees who finished that job named autonomy (Krishnan et al., 2015). Slåtten and Mehmetoglu, (2011) also stated that there was significant evidence that employee considers autonomy as freedom or independence linked to employee engagement. Meaning job autonomy positively influences employee engagement. For this reason, the second hypothesis that can be proposed is as follows:

$\mathrm{H}_{2}$ : Job autonomy positively influences employee engagement.

\section{Relationship between Strategic Attention and Employee Engagement}

There is a close link between strategy as a plan and strategy as behavior guidance as strategic attention. Sheemun et al., (2013) find that strategic attention can involve employees more engaged in the company. Supported by Robbins (2003) that good strategic attention will encourage employees to gained better commitment related to employee engagement. The better the strategic attention, the better the employee engagement. Slåtten and Mehmetoglu (2011) revealed that strategic attention is positively related to employee engagement. For this reason, the third hypothesis that can be proposed is:

$\mathrm{H}_{3}$ : Strategic attention positively influences employee engagement.

\section{Relationship between Role Benefit and Employee Engagement}

Kahn (1990) said roles within organization that depends on the resources employees got from an organization, will affect employee engage or disengage. Meaning, when organization gives employees opportunity in involving more deeply in their roles, the organization should provide with adequate resources to make an impact on employee engagement. Supported by Robbins (2003) and Slåtten and Mehmetoglu (2011) stated that the role of benefit given by the organization, the higher of employee engagement. For this reason, the fourth hypothesis that can be proposed is:

$\mathrm{H}_{4}$ : Role benefit positively influences employee engagement 
Based on the hypotheses earlier, the variables are goal-setting (GS), job autonomy (JA), strategic attention ( $\mathrm{SA}$ ), role benefit (RB), and employee engagement (EE). The conceptual framework can be concluded as follows:

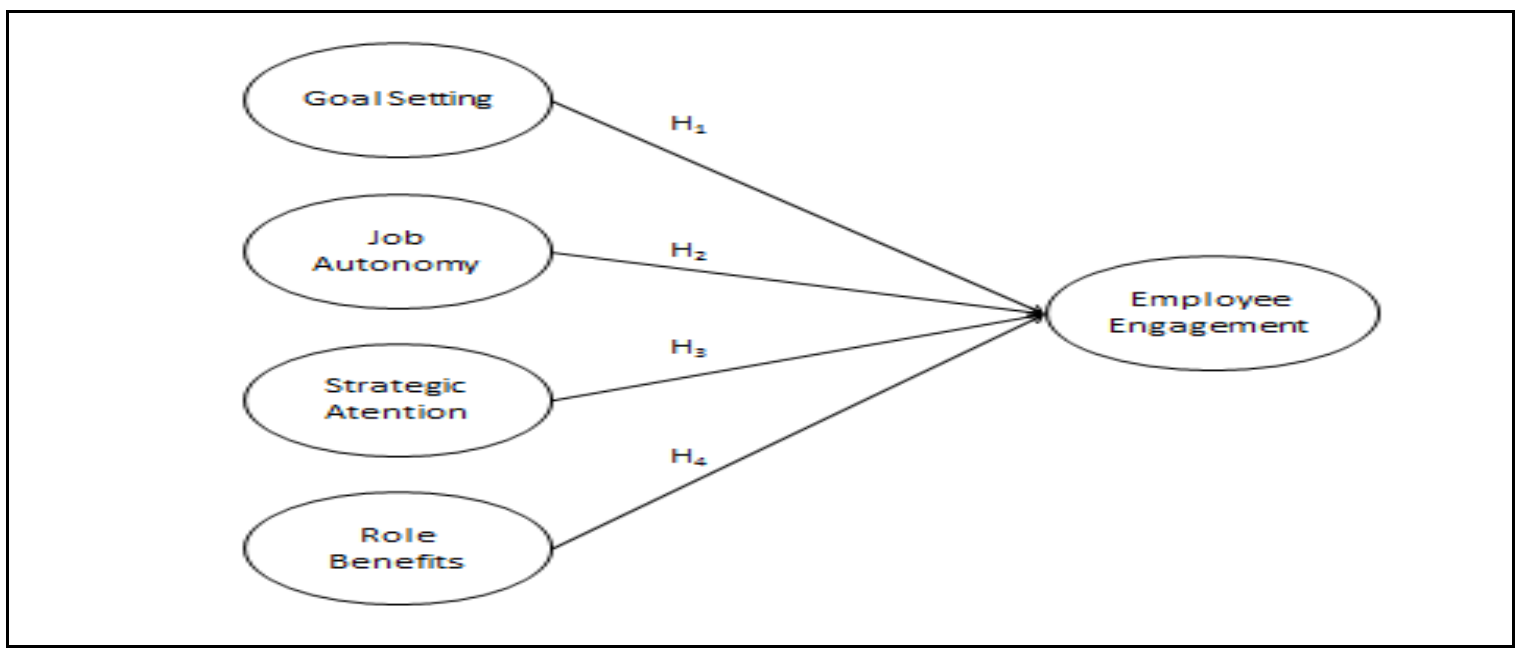

Figure 1. Research Model.

Source: Adapted from Sheemun et al., (2013)

\section{METHODOLOGY}

This research was done in $A B C$ oil Company. It was located in Pematang Siantar, North Sumatra. The population referred to the entire group of people, events, or things of interest that the researcher wished to investigate. This research is census research where all $A B C$ oil Company employees are respondents. Thus the results of data analysis are a picture of all $A B C$ Company employees. A list of questions in the questionnaire was developed based on the indicator examined and provided with multiple answers. It aimed to obtain a completed information on the research problems. The questionnaire described the five variables, such as goal setting, job autonomy, strategic attention, role benefit, and employee engagement. The questionnaire used a 7-point-Likert scale ranging from strongly disagree, disagree, rather disagree, neutral, quite agree, agree, to strongly agree.

\section{RESEARCH RESULTS}

The questionnaire was distributed to the employee at $A B C$ company. The following is a table describing the respondents' general profile (100 respondents). Characteristic of actual respondents are: majority gender is male $70 \%$ because this type of company is oil company need male employees for fields work more than female (30\%), then female employees only doing administrative work. Majority age is about 25-34 years of ages, as productive age of employee in Indonesia and still categorised as millenium worker. Education of repondents majority is diploma degree (75\%) meaning $A B C$ company is a good company with good employees standard of education to do their functional job with skill and knowledge as needed. Work duration majority is 2-5 years (52\%) can explain 
related purposes of study, then legally as permanent emplayees of $A B C$ should have minimum 2 years working experience at this company.

\section{Measurement Model}

The first test conducted was the outer model test, which aimed to see the ability to exist indicators to represent the variables. In testing the outer model by using PLS-SEM, a reliability test was done by revealing the convergent validity, discriminant validity, and composite reliability. The test was done to validate the questionnaire items by looking at the value of the outer loading of each indicator and the AVE value of each variable. The results of convergent validity testing on the measurement model can be seen in Table 1 and Table 2.

Table 1. Test Results for Convergent Validity Indicators

\begin{tabular}{|c|c|c|}
\hline Construct & Indicator & Outer loading \\
\hline \multirow{4}{*}{ Goal Setting } & $\begin{array}{l}\text { Individuals are rewarded } \\
\text { based on the } \\
\text { accomplishment of goals }\end{array}$ & 0,833 \\
\hline & $\begin{array}{l}\text { I am taught how to set an } \\
\text { effective goal }\end{array}$ & 0,857 \\
\hline & All my goals are specific & 0,915 \\
\hline & All my goals are measurable & 0,896 \\
\hline \multirow{4}{*}{ Job Autonomy } & $\begin{array}{l}\text { My work allows me to plan } \\
\text { my tasks }\end{array}$ & 0,894 \\
\hline & $\begin{array}{l}\text { I am able to decide how to } \\
\text { execute my work }\end{array}$ & 0,909 \\
\hline & $\begin{array}{l}\text { A lot of freedom in the } \\
\text { execution of my work }\end{array}$ & 0,799 \\
\hline & $\begin{array}{l}\text { The opportunity to decide } \\
\text { me the order of my work }\end{array}$ & 0,821 \\
\hline \multirow[t]{5}{*}{ Strategic Attention } & $\begin{array}{l}\text { I am conscious of doing my } \\
\text { job in line with the } \\
\text { company's vision }\end{array}$ & 0,765 \\
\hline & $\begin{array}{l}\text { Management has informed } \\
\text { about the company's aim }\end{array}$ & 0,802 \\
\hline & $\begin{array}{l}\text { The company communicates } \\
\text { the importance of my role in } \\
\text { the vision }\end{array}$ & 0,758 \\
\hline & $\begin{array}{l}\text { Put in extra effort beyond } \\
\text { what is expected to make } \\
\text { the company's successful }\end{array}$ & 0,788 \\
\hline & $\begin{array}{l}\text { Pass on knowledge of vision } \\
\text { to new employees }\end{array}$ & 0,760 \\
\hline \multirow[t]{3}{*}{ Role Benefit } & $\begin{array}{l}\text { The job gives me an } \\
\text { opportunity to show my } \\
\text { skills }\end{array}$ & 0,819 \\
\hline & I know my responsibilities & 0,838 \\
\hline & $\begin{array}{l}\text { I feel certain about how } \\
\text { much authority I have }\end{array}$ & 0,894 \\
\hline
\end{tabular}

22 Management and Economics Journal (MEC-J)

Vol 5 (1) April 2021 


\begin{tabular}{lll}
\hline & $\begin{array}{l}\text { Clear, planned goals } \\
\text { objectives exist for my job }\end{array}$ & 0,876 \\
\hline Employee Engagement & $\begin{array}{l}\text { I view my job as being } \\
\text { meaningful }\end{array}$ & 0,805 \\
\hline & I like to work intensely & 0,843 \\
\hline $\begin{array}{l}\text { I often become absorbed in } \\
\text { the job I am doing }\end{array}$ & 0,852 \\
\hline & The job gives me energy & 0,764 \\
\hline $\begin{array}{l}\text { I persevere when I } \\
\text { encounter challenges }\end{array}$ & 0,787 \\
\hline $\begin{array}{l}\text { I am willing to work } \\
\text { overtime }\end{array}$ & 0,792 \\
\hline
\end{tabular}

Table 1. presents the results of the convergent validity test. The results of the AVE of the convergence validity test can be seen in Table 2 below.

Table 2. Test Results for Validity of Convergent (AVE)

\begin{tabular}{lccc}
\hline Variable & AVE & Requirement & Result \\
\hline Employee & 0,603 & AVE $\geq 0,5$ & Valid \\
Engagement & 0,767 & AVE $\geq 0,5$ & Valid \\
Goal Setting & 0,735 & AVE $\geq 0,5$ & Valid \\
Job Autonomy & 0,735 & AVE $\geq 0,5$ & Valid \\
Role Benefit & 0,600 & AVE $\geq 0,5$ & Valid \\
Strategic Attention & & & \\
\hline
\end{tabular}

From the Table 2, it can be seen that the AVE value of all variables meets the requirements of convergent validity, which is more than 0,5 . The next step of the outer model testing used discriminant validity test with the Fornell-Larcker criteria. Discriminant validity could be measured by comparing the square root of each AVE value (in diagonal) with the correlation of coefficient (off-diagonal) according to each construct available. Indicators for different constructs required the square correlation value of each variable to be higher than the cross square correlation value with other variables (Hair et al., 2014). The discriminant validity would be achieved if the AVE of the square root values are higher than 0,7 and the AVE of the square root in the same variable is higher than the other correlation values. The results of the discriminant validity test can be seen in Table 3 .

Based on Table 3, it can be seen that the discriminant validity has met the specified condition, where the AVE of the square root value of each variable is higher than the cross-correlation value with other variables. Besides, the AVE of the square root values of each variable is all higher than 0,6 . Therefore, it can be concluded that the discriminant validity test has been fulfilled. 
Table 3. Test Results for the Validity Discriminant of Actual Results

\begin{tabular}{cccccc}
\hline & EE & GS & JA & RB & SA \\
\hline EE & 0,777 & & & & \\
GS & 0,613 & 0,876 & & & \\
JA & 0,702 & 0,675 & 0,857 & & \\
RB & 0,722 & 0,607 & 0,676 & 0,857 & \\
SA & 0,743 & 0,698 & 0,730 & 0,732 & 0,775 \\
\hline
\end{tabular}

Note: Employee Engagement (EE); Goal Setting (GS); Job Autonomy (JA); Role Benefit (RB); Strategic Attention (SA)

After conducting the validity test, reliability testing was done to measure the instrument/questionnaire. It can be done by looking at Cronbach's Alpha and existing composite reliability. According to Sekaran and Bougie (2016), reliability is the correlation of items, scales, or instruments that measure what should be done because the actual size is not available. The reliability must be estimated based on the correlation with what was considered correct. The coefficients are a form of relationship, and there are several types that represent various meanings of reliability based on Table 4.

Table 4. Reliability Test

\begin{tabular}{lcl}
\hline \multicolumn{1}{c}{ Variable } & Composite Reliability & Results \\
\hline Employee Engagement & 0,901 & Reliable \\
Goal Setting & 0,929 & Reliable \\
Job Autonomy & 0,917 & Reliable \\
Role Benefit & 0,917 & Reliable \\
Strategic Attention & 0,882 & Reliable \\
\hline
\end{tabular}

Based on the results of data processing using Smart-PLS 3.0, it can be seen that all variables have composite reliability values greater than 0,7 . Thus, it can be said that all construct variables are reliable.

\section{Structural Model}

Inner Model or evaluation of structural models aimed to predict the relationship between latent variables. The inner model could be measured by looking at the percentage variance (R-square value) (Hair, et al., 2014). R-square value can be seen in Table 5.

Table 5. R-square Value

\begin{tabular}{cc}
\hline Variable & R-Square \\
\hline Employee engagement & 0,648 \\
\hline
\end{tabular}

According to Ghozali (2016), an R-square value of 0,648 indicates a robust research model. Aside from looking at the R-square value, hypothesis testing was also done in the inner model testing. Hypothesis testing is not conducted t-test because this research is census research. Testing is done by paying attention to the direction of the standardized path coefficient. If the standardized path coefficient is positive, then the hypothesis is supported and vice versa. Table 6 shows that all standardized path coefficients are positive. Thus it can be concluded that all hypotheses are supported. 


\begin{tabular}{lll}
\hline \multicolumn{3}{c}{ Table 6. Hypothesis testing } \\
\hline Hypothesis & $\begin{array}{l}\text { Standardized path } \\
\text { coefficient }\end{array}$ & Decision \\
\hline $\begin{array}{l}\mathrm{H}_{1} \text { : Goal setting has a positive influence on } \\
\text { employee engagement. }\end{array}$ & 0,052 & Supported \\
$\begin{array}{l}\mathrm{H}_{2}: \text { Job Autonomy has a positive influence } \\
\text { on employee engagement. }\end{array}$ & 0,232 & Supported \\
$\begin{array}{l}\mathrm{H}_{3}: \text { Strategic attention has a positive } \\
\text { influence on employee engagement. }\end{array}$ & 0,316 & Supported \\
$\begin{array}{l}\mathrm{H}_{4}: \text { Role benefit has a positive influence } \\
\text { on employee engagement. }\end{array}$ & 0,302 & Supported \\
\hline
\end{tabular}

\section{DISCUSSION AND IMPLICATION}

Based on the results of the first hypothesis test, which stated that Goal Seeting has positive influence toward Employee Engagement, it can be seen by the results of the hypothesis testing, that the result of data was positive and significant. The hypothesis testing result supported the previous study done by by Ashraf et al., (2012); Bezuijen et al., (2010); Medlin \& Green, (2009); Slåtten \& Mehmetoglu, (2011). This shows that when the goal setting is done well, it will increase employee engagement. The work will work with enthusiasm and want to work overtime when employees feel that management is not stingy to give appreciation for the hard work of their employees. In addition, when the job description is clear, measurable, employees will enjoy the work, not giving up immediately when there are challenges in their work and energy that does not recede at work.

The next hypothesis test namely strategic attention has a positive influence on employee engagement, supported. These results are in accordance with studies from Shemuun et al. (2013) and Slåtten and Mehmetoglu, (2011). Attention strategy becomes a determining factor for employee engagement. Robbins (2016) explains that good stategic attention both will increase employee engagement. Good communication between the company and its employees is an important factor. Employees who understand their role in the company, know the vision and mission, and are aware of working more than expected, will have an impact on increasing employe engagement. When the employee works just to earn money, then the employee does not feel that he owns the company and becomes indifferent. The employee is quickly tempted to move to another company when there is an attractive offer. If this happens often, then the company's operations will be disrupted.

The next hypothesis is that the role benefit is also proved positively related to employee engagement. Is supported. This statement is in line with the results of studies in Kahn (1990); Robbins, (2003); Slåtten \& Mehmetoglu, (2011). Therefore, the company must implement a higher role benefit to obtain a higher employee engagement. This can be done by giving the employees an opportunity improving their skills, understanding their responsibilities, making them feel confident about how much authority they have, and giving a clear and planned goals for their work. 
When there is an engagement within the employees, they will behave more altruistic (voluntary actions) to the company. It can be seen from their willingness to submit ideas, information or suggestions on problems that occur within the company, or it is what is also called as voice behavior. This behavior benefits the company in various ways, such as improving the quality, both internally and externally, being capable of identify problems quickly, helping to make better changes, and being able to compete with other companies. Therefore, for small to middle class company, it is important to have ethical leaders to represent an great example of behavior to strengthen the employee engagement.

Hypothesis test results showed that job autonomy positively influences the employee engagement, supported. It implies that $A B C$ company should pay attention to their employee's autonomous job to obtain a higher employee engagement. These results are consistent with the results of studies from Krishnan et al. (2015); Slåtten and Mehmetoglu, (2011).

The job autonomy in HR management is an important thing to consider for both upper and middle level leaders because they will have a big influence on how employees will behave within the company. Job autonomy does not only see how the management in a company can manage employees, but also how time is efficiently distributed and the work is done effectively. $A B C$ company must implement a good job autonomy to establish positive feelings in the employees. These positive feelings will encourage them to act more or better. Before having this behavior, the employees need a unique motivation that will make them dedicate themselves fully to work physically, cognitively, and emotionally. This motivation is what so called as employee engagement.

\section{CONCLUSION, LIMITATIONS, SUGGESTION}

Goal setting at $A B C$ company positively influences employee engagement. The results that the first hypothesis is empirically supported. Therefore, the increase in goal setting increases the employee engagement. Then, Job autonomy at $A B C$ company positively influences employee engagement. The results show that the second hypothesis is empirically supported. It can be concluded that the increase in job autonomy increases the employee Engagement. While, Strategic attention at $A B C$ company positively influences the employee engagement. The results show that the third hypothesis is empirically supported. Thus, the increase in strategic attention increases the employee engagement. Finally, Role benefit at $A B C$ company positively influences employee engagement. The results show that the fourth hypothesis is empirically supported. Therefore, the increase in role benefit increases the employee engagement.

There are several limitations. First, there is limited time and location in conducting this research. It was conducted within three months and limited to only at $A B C$ company. Therefore, the results could not be generalized for other companies. Second, the respondents were limited to only 100 respondents. In fact, the more the samples, the better the results. 
Future researches are expected to conduct more in-depth observations or interviews with several respondents to have better understanding on the influence of goal setting, job autonomy, strategic attention and role benefit. Studies on other variables influencing goal setting, job autonomy, strategic attention and role benefit are also suggested and it is also possible to make comparisons between two companies or more.

\section{REFERENCES}

Anaza, N. A., \& Rutherford, B. N. (2012). Developing our understanding of patronizing frontline employees. Managing Service Quality: An International Journal, 22(4), 340358. https://doi.org/10.1108/09604521211253469

Ashraf, Z., Jaffri, A., \& Sharif, M. (2012). Increasing Employee Organizational Commitment by Correlating Goal Setting, Employee Engagement and Optimism at Workplace. European Journal of Business, 4(2), 71-77.

Bezuijen, X. M., van Dam, K., van den Berg, P. T., \& Thierry, H. (2010). How leaders stimulate employee learning: A leader-member exchange approach. Journal of Occupational and Organizational Psychology, 83(3), 673-693. https://doi.org/10.1348/096317909X468099

Chughtai, A. A, \& Buckley, F. (2011). Work engagement: Antecedents, the mediating role of learning goal orientation and job performance. Journal of Career Development International, 16 (7), 684-705.

Dobre, O.I. (2013). Employee Motivation and Organization Performance. Review of Applied Socio-Economic Research, 5 (1), 53-61.

Elanain, H. M. A. (2009). Job characteristics, work attitudes and behaviors in a nonwestern context: Distributive justice as a mediator. Journal of Management Development, 28(5), 457-477. https://doi.org/10.1108/02621710910955985

Ghozali, I. (2016). Aplikasi Analisis Multivariate dengan Program IBM SPSS 23. (Edisi 8). Semarang: Badan Penerbit Universitas Diponegoro.

Hackman, J. R., \& Oldham, G. R. (1976). Motivation through the design of work: test of a theory. Organizational Behavior and Human Performance, 16(2), 250-279. https://doi.org/10.1016/0030-5073(76)90016-7

Hair, J. F., Hult, G. T. M., Ringle, C. M., \& Sarstedt, M. (2014). Partial least squares structural equation modeling (PLS-SEM). Sage Publisher. https://doi.org/10.1108/EBR-10-2013-0128

Kahn, W. A. (1990). Psychological Conditions of Personal Engagement and Disengagement at Work. Academy of Management Journal, 33(4), 692-724. https://doi.org/10.2307/256287

King, C. (2010). One size doesn't fit all: Tourism and hospitality employees' response to internal brand management. International Journal of Contemporary Hospitality Management, 22(4), 517-534. https://doi.org/10.1108/09596111011042721 
Krishnan, R., Ismail, S., Ismail, I, Muhammed, R.N, Muthusamy, G., Kanchymalay, K. (2015).Employee Work Engagement: Understanding the Role of Job Characteristics and Employee Characteristics. Journal of Applied Environmental and Biological Sciences, 4(10S), 58-67.

Medlin, B., \& Green, K. W. (2009). Enhancing performance through goal setting, engagement, and optimism. Industrial Management and Data Systems, 109(7), 943956. https://doi.org/10.1108/02635570910982292

Prabhakar, G. V. (2011). The role of employee engagement in work-related outcomes. Interdisciplinary Journal of Research in Business Year, 1(3), 47-61.

Radda, A. A., Majidadi, M. A., \& Akanno, S. N. (2015). Employee Engagement in Oil and Gas Sector. International Journal of Management \& Organizational Studies, 4(3), 104116.

Robbins, P. Stephen. (2016). Human resources management.Jakarta: Salemba Empat.

Robbins, R. (2003). Harnessing “ Group Memory” to Build a Knowledge-Sharing Culture. Of Counsel.

Saks, A. M. (2019). Antecedents and consequences of employee engagement revisited. Journal of Organizational Effectiveness, 6(1), 19-38. https://doi.org/10.1108/JOEPP-062018-0034

Saks, A. M., \& Gruman, J. A. (2011). Getting newcomers engaged: The role of socialization tactics. Journal of Managerial Psychology, 26(5),383-402. https://doi.org/10.1108/02683941111139001

Schaufeli, W. B., \& Bakker, A. B. (2010). Defining and measuring work engagement: Bringing clarity to the concept. In Work Engagement: A Handbook of Essential Theory and Research. https://doi.org/10.4324/9780203853047

Sekaran, U., \& Bougie, R. (2016). Research Method for Business. In John Wiley \& Sons Ltd. https://doi.org/10.1017/CBO9781107415324.004

Sheemun, Y., Suhaimi, M. N., Abdullah, S. S., Rahman, A., \& Abdullah, O. Y. (2013). Employee Engagement: A Study from the Private Sector in Malaysia Nik Kamariah Nik Mat. Human Resource Management Research, 3(1), 43-48.

Slåtten, T., \& Mehmetoglu, M. (2011). Antecedents and effects of engaged frontline employees: A study from the hospitality industry. In Managing Service Quality, 21(1), 88-107. https://doi.org/10.1108/09604521111100261 